\title{
FUNGSI DPRD DALAM PROSES PEMBUATAN KEBIJAKAN PUBLIK (Studi Kasus di Kota Sungai Penuh)
}

\author{
Awal Khairi \\ STIA Nusantara Sakti Sungai Penuh \\ Email: \\ awalkhairi@gmail.com
}

\begin{abstract}
In carrying out its function as people's representatives, the Regional People's Representative Council has a function in the process of making public policies to increase knowledge of government in society. In addition, public policies can make people more fully participate in a government system. This function has been adjusted to the understanding of democracy and people's sovereignty where the people must carry out their duties as government participants in Sungai Penuh City. The formulation of the research problem is, What is the Function of the DPRD in the Public Policy Making Process (Case Study in Sungai Penuh City)? The research objective is to determine the function of DPRD in the Public Policy Making Process (Case Study in Sungai Penuh City). This research uses a qualitative approach where data is obtained through field interview guides to 5 informants referring to 5 research indicators, namely 1. Agenda setting process 2. Policy formulation process 3. Policy adoption process 4. Policy implementation process and 5. Policy evaluation process. The data obtained in the field were analyzed based on the classification of the informants' answers which were described in the results and discussion of the research which was then carried out by the interpreter of the researcher. It is known that the function of DPRD in the Public Policy Making Process (Case Study in Sungai Penuh City) of the five research indicators four indicators are well implemented, namely for the indicators of the policy formulation process, the policy adoption process, the policy implementation process, and the policy evaluation process while the process indicators The formulation of policies has not been carried out properly and this is in line with the theory of Purwo's opinion which the author makes as a proposal in research indicators. For this reason, the authors suggest that the function of DPRD in the Public Policy Making Process in Sungai Penuh City can be improved so that it can be maximized in carrying out its function in policy making.
\end{abstract}

Keywords: DPRD Function, Public Policy Making Process

\begin{abstract}
ABSTRAK
Dalam menjalankan fungsinya sebagai wakil rakyat, Dewan Perwakilan Rrakyat Daerah memiliki fungsi dalam proses pembuatan kebijakan publik dapat meningkatkan pengetahuan pemerintahan di masyarakat. Selain itu kebijakan publik dapat membuat masyarakat lebih maksimal dalam berpartisipasi di dalam sebuah sistem pemerintahan. Fungsi ini telah disesuaikan dengan paham demokrasi maupun kedaulatan rakyat dimana rakyat harus menjalankan tugas sebagai partisipan pemerintahan di Kota Sungai Penuh. Rumusan masalah
\end{abstract}


penelitian yaitu, bagaimanakah Fungsi DPRD Dalam Proses Pembuatan Kebijakan Publik (Studi Kasus di Kota Sungai Penuh)? Tujuan penelitian yaitu, Untuk mengetahui Fungsi DPRD Dalam Proses Pembuatan Kebijakan Publik (Studi Kasus di Kota Sungai Penuh). Penelitiaan ini menggunakan pendekatan kualitatif dimana data diperoleh melalui pedoman wawancara dilapangan kepada 5 orang informan yang mengacu kepada 5 indikator penelitian yaitu 1. Proses penyusunan agenda 2. Proses formulasi kebijakan 3. Proses adopsi kebijakan 4. Proses implementasi kebijakan dan 5. Proses evaluasi kebijakan. Data yang diperoleh dilapangan dianalisis berdasarkan pengklasifikasian jawaban informan yang diuraikan dalam hasil dan pembahasan penelitian yang kemudian dilakukan interpretatif peneliti. Diketahui bahwa Fungsi DPRD Dalam Proses Pembuatan Kebijakan Publik (Studi Kasus di Kota Sungai Penuh) dari lima indikator penelitian empat indikator yang terlaksana dengan baik yaitu untuk indikator Proses formulasi kebijakan, Proses adopsi kebijakan, Proses implementasi kebijakan, dan Proses evaluasi kebijakan sedangkan untuk indikator proses penyususnan kebijakan belum terlaksana dengan baik dan ini sejalan dengan teori pendapat Purwo yang penulis jadikan ajuan dalam indikator penelitian. Untuk itu penulis menyarankan agar Fungsi DPRD Dalam Proses Pembuatan Kebijakan Publik di Kota Sungai Penuh, dapat ditingkatkan agar lebih maksimal dalam menjalankan fungsinya dalam penyusunan kebijakan.

\section{Kata Kunci : Fungsi DPRD, Proses Pembuatan Kebijakan Publik}

\section{PENDAHULUAN}

Berdasarkan ketentuan Undang-Undang Dasar Negara Republik Indonesia tahun 1945, pelaksanaan penyelenggaraan negara dilakukan oleh lembaga- lembaga eksekutif, legislatif, dan yudikatif. Oleh karena itu didalam pelaksanaan penyelenggaraan Negara, rakyat menginginkan adanya penyelenggaraan yang mampu menjalankan fungsi dan tugasnya secara sungguh-sungguh dan penuh tanggung jawab agar reformasi pembangunan dapat berdaya guna dan berhasil. Dengan demikian, para penyelenggara Negara dalam menjalankan fungsi dan tugasnya tersebut, harus jujur, adil, terbuka, dan terpercaya serta mampu membebaskan diri dari praktek korupsi, kolusi dan nepotisme.

Penyelenggaraan Pemerintah Daerah dalam rangka otonomi daerah memerlukan inovasi baru dalam bidang pemerintahan secara keseluruhan. Dan sudah waktunya untuk difikirkan bagi kepentingan pemerintahan masa depan sebuah pola interaksi antara eksekutif dengan legislatif didaerah dengan menciptakan mekanisme "Cheeks and Balances" di tingkat lokal.

Dengan berlakunya Undang-Undang Nomor 23 Tahun 2014 Tentang Pemerintah Daerah telah menyebabkan terjadinya berbagai perubahan mendasar dalam penyelenggaraan pemerintahan daerah. Perubahan tersebut akan merubah peta pemerintahan secara keseluruhan di Indonesia termasuk perubahan terhadap pengawasan daerah yang akan berimplikasi pada perubahan pengawasan terhadap anggaran daerah. Penyelenggaraan pemerintahan daerah diarahkan untuk mempercepat terwujudnya kesejahteraan masyarakat melalui peningkatan pelayanan, pemberdayaan, dan peran serta masyarakat, serta 
peningkatan daya saing daerah dengan memperhatikan prinsip demokrasi, pemerataan, keadilan, dan kekhasan suatu daerah dalam sistem Negara Kesatuan Republik Indonesia.

Pemberian otonomi luas kepada Daerah membawa konsekuensi diperlukannya penyesuaian tata kelembagaan serta pola hubungan antar lembaga pengawasan dan pemeriksaan keuangan di daerah. Pengawasan merupakan tugas dan wewenang Dewan Perwakilan Rakyat Daerah sesuai Pasal 42 Ayat (1) butir c, Undang-Undang-Undang Nomor 23Tahun 2014 Tentang Pemerintah Daerah: "Dewan Perwakilan Rakyat Daerah mempunyai tugas dan wewenang melaksanakan pengawasan terhadap Peraturan Daerah dan Peraturan Perundang-undangan lainnya, peraturan kepala daerah, anggaran pendapatan belanja daerah, kebijakan pemerintah daerah dalam melaksanakan program pembangunan daerah, dan kerjasama internasional didaerah".

Substansi sasaran pokok yang hendak dicapai melalui perubahan sistem pemerintahan daerah adalah :

1. Pembangunan sistem dan kehidupan pemerintahan yang demokratis.

2. Penciptaan pemerintahan daerah yang bersih dan berwibawa dengan nuansa desentralisasi.

3. Pemberdayaan masyarakat agar mampu berperan serta secara optimal dalam penyelenggaraan pemerintahan dan pembangunan daerah.

4. Penegakan supremasi hukum Dalam rangka mewujudkan sasaran tersebut, Dewan Perwakilan Rakyat Daerah perlu mengupayakan langkah-langkah konkrit yang dapat mendorong perannya secara optimal dalam konteks pemerintahan daerah.

Adanya perubahan sistem daerah sangat ditentukan oleh adanya kebijakan yang diambil oleh pemerintah terlepas apakah kebijakan tersebut dibuat untuk kepentingan masyarakat ataupun untuk sekelompok atau golongan tertentu yang pasti dengan adanya kebijakan akan memberikan perubahan pada tatanan kehidupan masyarakat. Disinilah fungsi DPRD dituntut untuk dapat membuat kebijakan publik bersama pemerintah yang berwenang agar kebijakan tersebut dapat dimplrmrntasika dan bermanfaat bagi kehidupan masyarakat

Kebijakan yang dikeluarkan oleh DPRD sebagai perpanjangan tangan pemerintahan di daerah umumnya ditentukan oleh anggota organisasinya, demikian halnya dilingkungan daerah kebijakan yang dikeluarkan oleh pemerintah sangat menentukan nasib dari kehidupan masyarakat banyak dan DPRD mempunyai fungsi yang sangat strategis dalam pencapaian tujuan organisasi sehingga perlu diawasi agar adanya kebijakan publik yang betul-betul berpihak kepada kepentingan masyarakat.

Namun perlu diketahui pula, dalam menjalankan tugas dan fungsinya DPRD pasti melalui hambatan-hambatan yang sedikit banyak menganggu jalannya proses pembuatan kebijakan publik. Hambatan ini merupakan permasalahan awal atau fenomena secara internal maupun eksternal, contohnya secara internal yaitu rendahnya kualitas sumber daya manusia yang ada, sedangkan secara eksternal terbatasnya waktu yang ada dalam proses pembahasan kebijakan.

Dalam sebuah pemerintahan peran dan fungsi kebijakan publik menjadi leading sektor program pembangunan nasional, maka setiap output dari proses proses pemerintahan yang dilaksanakan oleh para elit pemerintahan yang tergabung dalam lembaga eksekutif dan legislatif.

Kebijakan publik merupakan kebijakan-kebijakan yang dibuat oleh pemerintah sebagai pembuat kebijakan untuk mencapai tujuan-tujuan tertentu di masyarakat di mana dalam penyusunannya melalui berbagai tahapan. Namun demikian, dalam pelaksanaannya masih terdapat kebijakan atau regulasi yang dihasilkan belum berorientasi kepada publik. Kasus-kasus yang terjadi pada pemerintahan adalah sebuah kebijakan yang berorientasi 
kepada kepentingan publik. Sistem pemerintahan merupakan suatu siklus yang mengintegrasikan para pelaku pemerintahan dalam menyerap aspirasi pemerintahan di masyarakat menjadi sebuah regulasi melalui dalam masyarakat seperti pengangkaan CPNS, kepala lembaga dan instansi hal tersebut dikarena adanya peran kebijakan publik dalam pembentukaan kebijakan pemerintahan, dimana masih perlu adanya integrasi persepsi dalam membuat kebijakan antara para pelaku pemerintahan yang berada dalam unsur Kebijakan Publik dalam pembentukan kebijakan di daerah.

Timbulnya kebijakan yang dipandang tidak adil oleh beberapa masyarakat yang berkepentingan, hendaknya diketahui dan dijadikan aspirasi oleh para unsur Kebijakan Publik sebagai upaya perbaikan kebijakan selanjutnya, namun demikian halnya seperti Partai pemerintahan, Kelompok Kepentingan, Kelompok Penekan, Media Sosial dan Tokoh Masyarakat, saat ini seolah tidak berada dalam garis integritas pada sebuah sistem pemerintahan yang baik. Kondisi ini terlihat dari perilaku masing-masing unsur Kebijakan Publik itu sendiri, dimana partai pemerintahan sibuk memperluas jaringan kekuasaan masingmasing partai sehingga terkadang timbul konflik baik dalam internal partai itu sendiri maupun dengan partai yang lainnya.

Kelompok kepentingan terkadang dijadikan alat pemerintahan sehingga mereka tidak lagi memahami peran dan fungsinya dalam pembentukan sebuah kebijakan publik pada sistem pemerintahan yang di jalankan saat ini, kelompok penekan sibuk dengan membuka kelemahan-kelemahan pemerintahan yang sedang berdiri yang di afiliasikan melalui media masa. Tokoh pemerintahan yang seharusnya menjadi sentral stabilisator bangsa, terkadang terjebak dengan situasi pemerintahan kepentingan yang berdampak kepada timbulnya kelompok-kelompok masyarakat. Kondisi ini cukup memprihatinkan apabila terus berjalan, di satu sisi para elit pemerintahan sibuk untuk mendapatkan kekuasaan, di sisi lain masyarakat menunggu keberpihakan pemerintah atas harapan-harapannya.

\section{METODE PENELITIAN}

Pendekatan yang digunakan dalam penelitian ini adalah pendekatan kualitatif, yaitu suatu proses penelitian dan pemahaman yang berdasarkan pada metodologi yang menyelediki suatu fenomena sosial dan masalah manusia.

Menurut Sugiyono (2017, hlm. 8) mengatakan bahwa: "Metode penelitian kualitatif sering disebut metode penelitian naturalistik karena penelitiannya dilakukan pada kondisi yang alamiah (natural setting); disebut juga sebagai metode etnographi, karena pada awalnya metode ini lebih banyak digunakan untuk atropologi budaya; disebut sebagai metode kualitatif, karena data yang terkumpul dan analisisnya lebih bersifat kualitatif".

\section{HASIL PENELITIAN}

\section{A. Defenisi Operasional variabel}

Menurut Purwo, (2012:39) yaitu ada 5 proses dalam pembuatan kebijakan publik yaitu:

\section{Proses Penyusunan Agenda}

proses masuknya agenda- agenda kepada DPRD yang harus segera dicarikan solusi atau jalan keluarnya sehingga menghasilkan suatu kebijakan publik. Para pejabat yang dipilih dan diangkat menempatkan masalah pada agenda publik. Sebelumnya masalah ini 
berkompetisi terlebih dahulu untuk dapat masuk dalam agenda kebijakan. Pada akhirnya, beberapa masalah masuk ke agenda kebijakan para perumus kabijakan. Pada tahap ini mungkin suatu masalah tidak disentuh sama sekali, sementara masalah yang lain ditetapkan menjadi fokus pembahasan, atau ada pula masalah karena alasan-alasan tertentu ditunda untuk waktu yang lama.

\section{Proses Formulasi Kebijakan}

Masalah yang telah masuk ke agenda kebijakan kemudian dibahas oleh para pembuat kebijakan. Masalah-masalah tadi didefinisikan untuk kemudian dicari pemecahan masalah terbaik. Pemecahan masalah tersebut berasal dari berbagai alternatif atau pilihan kebijakan (policy alternatives/policy options) yang ada. Dalam perumusan kebijakan masing-masing alternatif bersaing untuk dapat dipilih sebagai kebijakan yang diambil untuk memecahkan masalah. Dalam tahap ini masing-masing actor akan bersaing dan berusaha untuk mengusulkan pemecahan masalah terbaik.

\section{Proses Adopsi Kebijakan}

Dari sekian banyak alternatif kebijakan yang ditawarkan oleh para perumus kebijakan, pada akhirnya salah satu dari alternative kebijakan tersebut diadopsi dengan dukungan dari mayoritas legislatif, konsensus antara direktur lembaga atau putusan peradilan.

\section{Proses Implementasi Kebijakan}

Suatu program kebijakan hanya akan menjadi catatan-catatan elit jika program tersebut tidak diimplementasikan, yakni dilaksanakan oleh badan-badan administrasi maupun agen-agen pemerintah di tingkat bawah. Kebijakan yang telah diambil dilaksanakan oleh unit-unit administrasikan yang memobilisasikan sumber daya finansial dan manusia. Pada tahap implementasi ini berbagai kepentingan akan saling bersaing. Beberapa implementasi kebijakan mendapat dukungan para pelaksana (implementors), namun beberapa yang lain mungkin akan ditentang oleh para pelaksana.

\section{Proses Evaluasi Kebijakan}

Dalam tahap ini kebijakan yang telah dijalankan akan dinilai atau dievaluasi, untuk melihat sejauh mana kebijakan yang dibuat untuk meraih dampak yang diinginkan, yaitu memecahkan masalah yang dihadapi masyarakat. Oleh karena itu ditentukan ukuranukuran atau kriteria-kriteria yang menjadi dasar untuk menilai apakah kebijakan publik yang telah dilaksanakan sudah mencapai dampak atau tujuan yang diinginkan atau belum.

\section{IV.SIMPULAN}

\section{1. agenda Proses penyusunan kebijakan}

A. Dalam prosesdur penyusunan agenda, Dewan Perwakilan Daerah Rakyat (DPRD) Kota Sungai Penuh menerima laporan permasalahn yang masuk kemudian diagendakan, setelah itu dilihat mana yang permasalahn yang harus mendapat prioritas untuk segera disidangkan.

B. fungsi Dewan Perwakilan Rakyat Daerah (DPRD) dalam proses penyusunan agenda kebijakan belum dilaksanakan sesuai dengan jadwalnya dikarenakan banyaknya persoalan yang mendesak yang harus diselesaikan terlebih dahulu.

C. Hasil dari proses penyusunan agenda akan menjadi tugas bagi DPRD untuk dapat menjalankan fungsinya dalam membuat suatu kebijakan publik

\section{Proses formulasi kebijkan}


A. Dalam prosedur formulasi kebijakan anggota Dewan Perwakilan Rakyat Daerah (DPRD) Kota Sungai Penuh melakukan pemilahan mana permasalahn yang harus segera dicarikan jalan keluarnya dan membuat suatu kebijakan

B. fungsi Dewan Perwakilan Rakyat Daerah (DPRD) dalam proses formulasi kebijakan publik sudah dilaksanakan dengan baik sesuai dengan peraturan yang ada sehingga masalah-masalah yang muncul dapat ditanggulangi dengan baik dan dapat dicarikan solusinya.

C. Hasil dari proses formulasi kebijkan akan menjadi suatu tumpukan permasalahanpermasalahn yang ditampung oleh DPRD Kota Sungai Penuh itulah yang dijadikan bahan untuk menentukan mana permasalahn yang harus didahulukan dicarikan solusinya dalam membuat kebijakan

\section{Proses adopsi kebijakan}

A. Prosedur adopsi kebijakan merupakan proses dimaan kebijakan yang akan dibuat dapat diadopsi dari ususlan anggota atau pihak tertentu yang disepakati dan disetujui secara bersama dalam suatu siadng sehingga dpat menjadi suatu kebijakan.

B. Fungsi Dewan Perwakilan Rakyat Daerah (DPRD) dalam proses adopsi kebijakan publik sudah dilaksanakan dengan baik sesuai dengan peraturan yang ada dimana bisa saja rumusan kebijakan yang ditawarkan diadopsi dan didukung oleh legislatif lembaga serta putusan peradilan dan akhirnya akan menghasilkan suatu kebijakan publik.

C. Hasil dari proses adopsi kebijakan akan menjadi suatu kebijakan publik apabila disepakati dan disetujui oleh pihak-pihak yang berwenang

\section{Proses implementasi kebijakan}

A. Prosedur implementasi kebijkan merupakan kebijkan yang sudah disetujui dan disahkan kemudian diimplementasikan kepada masyarakat.

B. Fungsi Dewan Perwakilan Rakyat Daerah (DPRD) dalam proses implementasi kebijakan publik sudah dilaksanakan dengan baik sesuai dengan peraturan yang ada dimana kebijakan tersebut harus dapat diterapkan apalagi kebijakan tersebut menyangkut kepentingan masyarakat di Kota Sungai Penuh.

C. Hasil dari proses implemntasi kebijakan mrupakan kebijakan baru yang sudah disahkan yang kemudian diimplementasikan kepada masyarakat agar kebijkan tersebut tidak hanya sekedar wacana saja

\section{Proses evaluasi kebijakan}

A. Prosedur evaluasi kebijakan merupakaan suatu proses dimana kebijakan tersebut setelah diimplementasikan kemudian dilakukan evaluasi untuk melihat sejauhmana kebiajakan tersebut meraih apa yag diharapkan.

B. Fungsi Dewan Perwakilan Rakyat Daerah (DPRD) dalam proses evaluasi kebijakan publik sudah dilaksanakan dengan baik sesuai dengan peraturan yang ada dimana proses evaluasi penting dilakukan agar kebijakan yang sudah disahkan betul-betul memberikan dampak yang positif dan menguntungkan bagi masyarakat Kota Sungai Penuh.

C. Hasil dari evaluasi kebijakan merupakan tolok ukur bagi DPRD Kota Sungai Penuh untuk dapat melihat sejauhmana kbeijakan tersebut berdampak posistif kepada masyarakat. 


\section{UCAPAN TERIMA KASIH}

Diucapkan terima kasih kepada semua pihak yang telah berkontribusi dalam penulisan jurnal ini, sehingga jurnal ini dapat diselesaikan dengan baik. Dan juga terima kasih kepada penglola jurnal Qawwam, sehingga bisa dipublikasan di OJS Qawwam.

\section{DAFTAR PUSTAKA}

Anderson, James E. 2009. Public Policy Making. Boston: Houghton Mifflin.

Bugin, B 2003, Analisis Data Penelitian Kualitatif, Rajawali Pers : Jakarta.

Danim, Sudarwan. 2002, Menjadi Peneliti Kualitatif, Pustaka Setia. Bandung

Pebi Julianto. 2018. Pengaruh Pengetahuan dan Keterampilan Terhadap Prestasi Kerja Pegawai Pada Mtsn Model Sungai Penuh. E Jurnal Administrasi Nusantara. Sungai Penuh.

Dunn, William N. 2003. Analisis Kebijakan Publik. Yogyakarta: Gadjah Mada University Press.

Emzir, 2010. Metodologi Penelitian Kualitatif Analisis Data, Jakarta: Rajawali Pers.

Fadillah. 2003, Paradigma Kritis Dalam Studi Kebijakan Publik, Yogyakarta.

Flippo. 2004. Efektifitas Kerja. Penerbit Ghalia Indonesia.

Pebi Julianto. 2018. Pengaruh Sistem Kearsipan Terhadap Efisiensi Kerja Pada koantor Camat Air Hangat Kabupaten Kerinci. E Jurnal Administrasi Nusantara. Sungai Penuh.

Paul H. Dauglas, Wahyudi Kumorotomo 1992. Ketentuan Transparansi dalam Pelayanan Publik.

G.R. Terry. 2006. Manajemen Sumber Daya Manusia. CV.Andi Karya Yogyakarta

Lexy J. Moleong. 2009. Metode Penelitian Kualitatif. Erlangga. Jakarta

Harold Koontz and Weihrich, Heinz. 2006. Human Resources Management, McGraw-Hill Irwin.

Miriam B. 2005.Dasar-Dasar Ilmu Politik.Jakarta : PT. Gramedia Pustaka Utama.

Moh Nazir. 2005. Metode Penelitian.Jakarta : Ghalia Indonesia 
Purwo, Palan. 2012. Manajemen Sumber Daya Manusia. Bumi Aksara. Jakarta

Pebi Julianto. 2019. Pengaruh Disiplin Kerja Terhadap Prestasi Kerja Pegawai pada Puskesmas di kecamatan Depati VII Kabupaten Kerinci. E Jurnal Administrasi Nusantara. Sungai Penuh.

Umar. 2005. Manajemen Sumber Daya Manusia. Penerbit BPFE - UGM

Sugiyono. 2007. Metode Penelitian kuantitatif da kualitatif dan $R \& D$. Alfabeta. Bandung

Soekidjo Notoatmodjo. 2002. Pengembangan Sumber Daya Manusia. Jakarta: PT. Ranika

Wahyudi Iskandar dkk. 2017. Implemtasi fungsi pengawsan DPRD dalam Kebijakan Pemerintahan Daerah di Kota Samarinda. Jurnal Ilmiah

Pebi Julianto. 2014. Evaluasi Pelaksanaan Program Satu milyar Satu kecamatan (Samisake) di kecamatan Depati Tujuh Kabupaten Kerinci Provinsi jambi tahun 2014. OSF Preprints. Jakarta.

Widodo. 2001. Budaya Organisasi: Sebuah Kebutuhan untuk Meningkatkan Kinerja Jangka Panjang. Jakarta. PT. Rajawali Pers.

UUD Negara RI 1945 Tentang Pelaksanaan Penyelenggaraan Negara

UU No. 25 Tahun 2008 Tentang Pembentukan Kota Sungai Penuh

UU Nomor 27 Tahun 2009 Tentang DPRD

UU.No. 32 Tahun 2014 Tentang Pemerintahan Daerah 